\title{
Sistem pengolahan lahan tanpa bakar dalam kebakaran hutan dan lahan pada kawasan gambut Kecamatan Bukit Batu Kabupaten Bengkalis
}

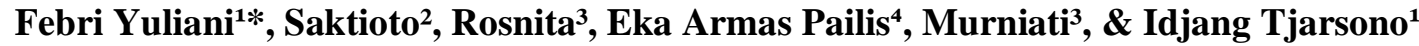 \\ ${ }^{1}$ Fakultas Ilmu Sosial dan Ilmu Politik, Universitas Riau \\ ${ }^{2}$ Fakultas Matematika dan Ilmu Pengetahuan Alam, Universitas Riau \\ ${ }^{3}$ Fakultas Pertanian, Universitas Riau \\ ${ }^{4}$ Fakultas Ekonomi dan Bisnis,Universitas Riau \\ * Febby_sasha@yahoo.co.id
}

\begin{abstract}
Abstrak. Kebakaran hutan merupakan masalah yang krusial dan perlu penanganan yang sungguh-sungguh, karena kebakaran ini disamping menyebabkan terjadinya gangguan lingkungan hidup dari asap yang timbul juga berakibat hilangnya potensi hutan dan penuruanan keanekaragaman hayati. Oleh sebab itu perlu dilakukan suatu upaya pengendalian kebakaran hutan yang efektif dan efesien. Kabupaten Bengkalis merupakan salah satu kabupaten yang terdapat di Provinsi Riau. Pada kegiatan Desa Binaan yang akan dilakukan adalah pada Kecamatan Bukit Batu, hal ini dilakukan mengingat bahwa Kecamatan Bukit Batu memiliki potensi pengembangan berbagai aspek ekonomi dan sosial dan dengan kondisi gambut yang luas, hal inilah yang menarik tim pengabdian masyarakat Universitas Riau untuk melakukan Desa Binaan dikawasan tersebut. Identifikasi masalah antara lain: kelembagaan yang belum optimal dan kurang seriusnya pemerintah dan kelompok tani untuk melakukan sistem pengolahan lahan tanpa bakar dalam menanggulangi kebakaran hutan dan lahan pada kawasan gambut yang disebabkan oleh kurangnya informasi dan teknologi dan kelembagaan dalam pengolahan lahan tanpa bakar. Tujuan dari pelaksanaan kegiatan ini adalah: Meningkatkan keterampilan masyarakat di Kecamatan Bukit Batu Kabupaten Bengkalis sehingga mampu menerapkan teknik membuka lahan pertanian tanpa bakar, pengelolaan air, dan budidaya pertanian di lahan gambut, serta panen dan pasca panen. Meningkatkan keterampilan masyarakat sehingga mampu memperkuat kelembagaan, analisis usaha dan pasar, serta penumbuhan jiwa kewirausahaan. Metode pengabdian dilakukan beberapa tahap yaitu: (1) Tahap Persiapan, (2) Tahap Penyusunan Program Kerja, (3) Tahap Pelaksanaan Workshop, (4) Tahap Pelaksanaan Pendampingan, (5) Tahap Monitoring dan Evaluasi program, dan (6) Tahap Pelaporan. Dari pengabdian Desa Binaan ini diketahui bahwa: kebakaran hutan dan lahan bukan semata-mata karena faktor alam berupa kekeringan. Faktor alam menyediakan kondisi untuk terjadinya kebakaran, tetapi manusia juga memegang peranan penting. Kebakaran hutan yang disebabkan oleh manusia terjadi karena adanya aktifitas Masyarakat lokal memiliki peran kontrol yang sangat substansial dalam pengembangan desa karena kontrol terhadap proses pengambilan keputusan harus diberikan kepada mereka yang nantinya menanggung akibat pengembangan termasuk kegagalan atau dampak negatif yang terjadi akibat pengembangan Desa. Oleh karena itu, kewenangan pengambilan keputusan harus diberikan kepada masyarakat lokal. Parameter partisipasi masyarakat dalam pengawasan adalah keterlibatan dalam tim pengawasan berikut kewenangan yang dimiliki.
\end{abstract}

Kata kunci: kebakaran hutan dan lahan; system; membuka lahan tanpa bakar; kelembagaan 
Assistance Implementation Stage, (5) Program Monitoring and Evaluation Stage, and (6) Reporting Phase. From the devotion of the Fostered Village it is known that: forest and land fires are not solely due to natural factors such as drought. Natural factors provide conditions for fires to occur, but humans also play an important role. Human-caused forest fires occur due to activities Local communities have a very substantial control role in village development because control of the decision-making process must be given to those who later bear the consequences of development including failure or negative impacts that occur due to village development. Therefore, decision making authority must be given to local communities. The parameter of community participation in supervision is involvement in the supervision team and their authority.

Keywords: forest and land fires; systems; land clearing without burning; institutional

To cite this article: Yuliani, F., Saktioto, Rosnita, E. A. Pailis, Murniati, \& I. Tjarsono. 2019. Sistem pengolahan lahan tanpa bakar dalam kebakaran hutan dan lahan pada kawasan gambut Kecamatan Bukit Batu Kabupaten Bengkalis. Unri Conference Series: Community Engagement 1: 645-651 https://doi.org/10.31258/unricsce.1.645-651

Peer-review under responsibility of the organizing committee of Seminar Nasional Pemberdayaan Masyarakat 2019

\section{PENDAHULUAN}

Kecamatan Bukit Batu terdiri dari satu kelurahan dan 14 desa. Salah satu kelurahannya yakni Kelurahan Sungai pakning menjadi Pusat/Kota Kecamatan. Secara umum, Kecamatan Bukit Batu memiliki banyak sumber potensi yang bisa dikembangkan khususnya disektor pertanian. Pengembangan dan pemanfaatan lahar pertanian yang ada berupa kawasan gambut merupakan tantangan tersendiri, perlu penataan system pertanian termasuk didalamnya adalah kelembagaan agar tidak terjadi kebakaran hutan dan lahan serta system pertanian yang mendukung pada pembukaan lahan tanpa bakar.

Berbagai Aspek yang akan dilibatkan dalam pengabdian ini antara lain : (a.) aspek tenologi yaitu : (1). Anggota kelompok yang merupakan kelompok petani yang memiliki kemampuan dalam pengolahan beberapa produk olahan pertanian . (2). Teknologi yang dimiliki anggota kelompok masih sederhana. Kelompok belum mampu membuat system pengolahan lahan tampa bakar yang baik dan berkelanjutan. (3). Pemahaman yang dimiliki anggota kelompok belum memadai, sehingga kelompok belum memanfaatkan atau belum mengolah lahan tanpa bakar secara baik dengan dukungan teknologi dan kelembagaan . (b). aspek ekonomi, meliputi : (1). Pembukaan dan pengelolaan dengan sistem pengolahan lahan tanpa bakar akan meningkatkan kemampuan ekonomi masyarakat (2). Keterbatasan peralatan, pengetahuan dan teknologi, menyebabkan pengolahan lahan tanpa bakar tidak maksimal dilaksanakan. (3). Anggota kelompok pada umumnya memiliki kebun sehingga penerapan tenologi relatif tidak akan kesulitan untuk menerapkan system tanpa bakar tersebut. (c). Aspek kelembagaan, meliputi : (1).Kelompok tani merupakan kelebagaan yang dapat meimplementasikan system pengolahan lahan tanpa bakar (2). Namun kelompok usaha belum tertata dengan baik. Baru hanya sebagai kumpulan petani saja. Kelompok belum memilki kelembagaan yang resmi. (3). Kelompok tani yang ada belum mampu mewadahi kebutuhan anggotanya tentang teknologi, pengetahuan dan kelembagaan

Berdasarkan kondisi ini kelompok tani tersebut sangat prospektif untuk dilakukan pembinaan. Melalui program pengabdian Universitas Riau ini diharapkan masyarakat termotivasi menghargai lingkungan dan menjaga kelestariannya dan keberlanutan ekolistem lahan gambut.

Berdasarkan potensi dari Kecamatan Bukit Batu Kabupaten Bengkalis memiliki letak geografis yang strategis dengan lahan gambut yang luas. Untuk Hal tersebut road maping dalam kurung 3 tahun kedepan. Sehingga dapat digambarkan identifikasi dan perumusan masalah dalam setiap tahunnya. Pengabdian desa binaan ini, dalam tahun pertamanya akan mengidentifikasikan dan merumuskan masalah sebagai berikut:(1).Kelembagaan yang ada saat ini masih belum kuat untuk mengajak masyarakat mengunakan sistem pengolahan lahan tanpa bakar dalam menanggulanggi kebakaran hutan dan lahan pada kawasan gambut yang disebabkan oleh kurangnya informasi dan teknologi dalam pengolahan lahan tanpa bakar. (2). Kurangnya keseriusan pemerintah dan anggota kelompok untuk melakukan sistem pengolahan lahan tanpa bakar dalam menanggulanggi kebakaran hutan dan lahan pada kawasan gambut yang disebabkan oleh kurangnya informasi 
dan teknologi dalam pengolahan lahan tanpa bakar. (3). Kurangnya pemahaman terhadap aspek teknologi pengolahan lahan tanpa bakar dalam menanggulanggi kebakaran hutan dan lahan pada kawasan gambut yang disebabkan oleh kurangnya informasi dan teknologi dalam pengolahan lahan tanpa bakar.

\section{METODE PENERAPAN}

Maksud dari pelaksanaan kegiatan ini adalah sebagai wujud kepedulian Universitas Riau dalam mencegah terjadinya kebakaran hutan dan lahan (karhutla) dengan cara membuka lahan dengan teknik tanpa bakar lahan untuk pertanian serta meningkatkan perekonomian masayarakat di Kecamatan Bukit Batu Kabupaten Bengkalis.Tujuan dari pelaksanaan kegiatan ini adalah: (1) Meningkatkan keterampilan masyarakat di Kecamatan Bukit Batu Kabupaten Bengkalis sehingga mampu menerapkan teknik membuka lahan pertanian tanpa bakar, pengelolaan air, dan budidaya pertanian di lahan gambut, serta panen dan pasca panen. (2) Meningkatkan keterampilan masyarakat sehingga mampu memperkuat kelembagaan, analisis usaha dan pasar, serta penumbuhan jiwa kewirausahaan. (3) Membentuk perilaku masyarakat membuka lahan pertanian tanpa bakar, pengelolaan air, dan budidaya pertanian di lahan gambut berkelanjutan, serta panen dan pasca panen. (4) Mewujudkan pembangunan pertanian berwawasan lingkungan yang menguntungkan serta transformasi teknologi dan informasi untuk mengaktifkan kelompok usaha tani memotivasi kelompok agar dapat berkelanjutan.

Empat Manfaat Kegiatan, (1) Bagi Masyarakat, Bagi Masyarakat Kecamatan Bukit Batu Kabupaten Bengkalis. Melalui sitem pengolahan lahan tanpa bakar berupa bantuan paket teknologi pengolahan dan kelembagaan diharapkan anggota kelompok usaha termotivasi untuk mengembangkan usaha pengolahan lahan tanpa bakar dan memiliki ketrampilan dalam pengolahan, perhitungan kelembagaan Selain itu diharapkan terjalin kontak komunikasi yang saling menguntungkan antara anggota kelompok tani dengan masyarakat serta pemerintah. Dengan demikian diharapkan pengolahan lahan tanpa bakar berkembang di Kabupaten Bengkalis khususnya dan Provinsi Riau umumnya mampu menghasilkan produk pertanian yang ramah lingkungan yang akan meningkatkan pendapatan dan kesejahteraan petani secara berkelanjutan serta penguatan kelembagaan untuk menerapkan system pengolahan lahan tanpa bakar. (2) Pelaksana (Perguruan Tinggi), (a) Salah satu strategi untuk semakin mendekatkan diri kepada masyarakat, dengan menerapkan ilmu pengetahuan yang sedang berkembang. (b) Mengetahui permasalahan yang dihadapi masyarakat untuk seterusnya dapat menjadi bahan kajian pengembangan ilmu pengetahuan dan teknologi yang bermanfaat bagi masyarakat. (c) Pemerintah Daerah Kecamatan Bukit Batu Kabupaten Bengkalis.

Adapun peserta atau sasaran dari kegiatan ini adalah masyarakat Kecamatan Bukit Batu Kabupaten Bengkalis, terutama adalah kelompok tani, kelompok usaha ibu-ibu dan masyarakat lainnya yang berminat akan menjadi sasaran dari Program Bina Desa Universitas Riau ini. Pada tahap awal direncanakan akan dibentuk dua kelompok sistem pengolahan lahan tanpa bakar sebagai kelompok tani yang akan fokus dibina menjadi kelompok dengan pengolahan lahan tanpa bakar. Kelompok tani ini akan dibina dari aspek teknologi dan kelembagaan.

Riau mempunyai lapisan gambut terdalam di dunia, yaitu mencapai 16 meter terutama di wilayah Kuala Kampar. Namun demikian selama dua dasa warsa terakhir, konversi lahan gambut terutama menjadi lahan pertanian, perkebunan kelapa sawit dan kayu kertas (pulp wood) diperkirakan telah merusak lahan gambut dengan segala fungsi ekologisnya.

Di pihak lain Lahan gambut merupakan suatu ekosistem yang unik dan rapuh, karena lahan ini berada dalam suatu lingkungan rawa, yang terletak di belakang tanggul sungai. Pembukaan lahan gambut melalui penebangan hutan (land clearing) dan drainase yang tidak hati-hati akan menyebabkan penurunan permukaan (subsiden) permukaan yang cepat, pengeringan yang tak dapat balik (irreversible drying), dan mudah terbakar.

Potensi gambut yang sangat besar di wilayah ini perlu dikelola secara arif sehingga dapat memberikan nilai tambah tanpa merusak fungsi alami lahan gambut itu sendiri. Restorasi gambut yang menyelaraskan antara fungsi ekonomi dan fungsi ekologi akan memberikan dampak positif dalam pembangunan yang berwawasan lingkungan.

Daerah rawa gambut pada umumnya datar dan terletak diantara dua sungai besar. Meskipun disebut datar, lahan rawa gambut ini pada umumnya berbentuk kubah (dome), sehingga terdapat beda ketinggian (elevation) antara pinggir sungai dan tengah diantara dua sungai tersebut sebagai puncak dome. Dalam kondisi tertentu memungkinkan terjadi pergerakan air dari puncak dome ke arah pinggir sungai. Pergerakan air inilah yang memungkinkan ekosistem rawa bergambut dapat menunjang kehidupan. 
Pemerintah Provinsi Riau mengembangkan perkebunan kelapa sawit melalui program K2I maupun program-program kebun kabupaten sebagai upaya mensejahterakan masyarakat. Upaya-upaya tersebut, menjadikan daerah ini memiliki luas kebun kelapa sawit yang terluas di Indonesia, yaitu 25\% dari total luas kebun kelapa sawit secara nasional. Luas lahan perkebunan kelapa sawit yang tercatat adalah sebesar 2.056.008 ha (Dinas Perkebunan Provinsi Riau, 2009).

Pengembangan kebun kelapa sawit di Provinsi Riau akan mengkonversi lahan gambut, karena sebesar kurang lebih 4 juta hektar dari daratannya terdiri atas lahan gambut (BBSDL, 2009). Konversi lahan gambut akan meningkatkan laju oksidasi sehingga rentan kebakaran, subsiden, banjir, dan intrusi air laut. Gangguan fungsi rawa gambut juga dapat menyebabkan lepasnya karbon ke atmosfer dan mendorong laju perubahan iklim (CCFPI, 2005; Las, Nugroho dan Hidayat, 2008).

Kerangka pemikiran kegiatan "Sistem Pengolahan Lahan Tanpa Bakar Dalam Kebakaran Hutan Dan Lahan Pada Kawasan Gambut Kecamatan Bukit Batu Kabupaten Bengkalis" secara simplifikasi disajikan pada gambar 1 berikut:

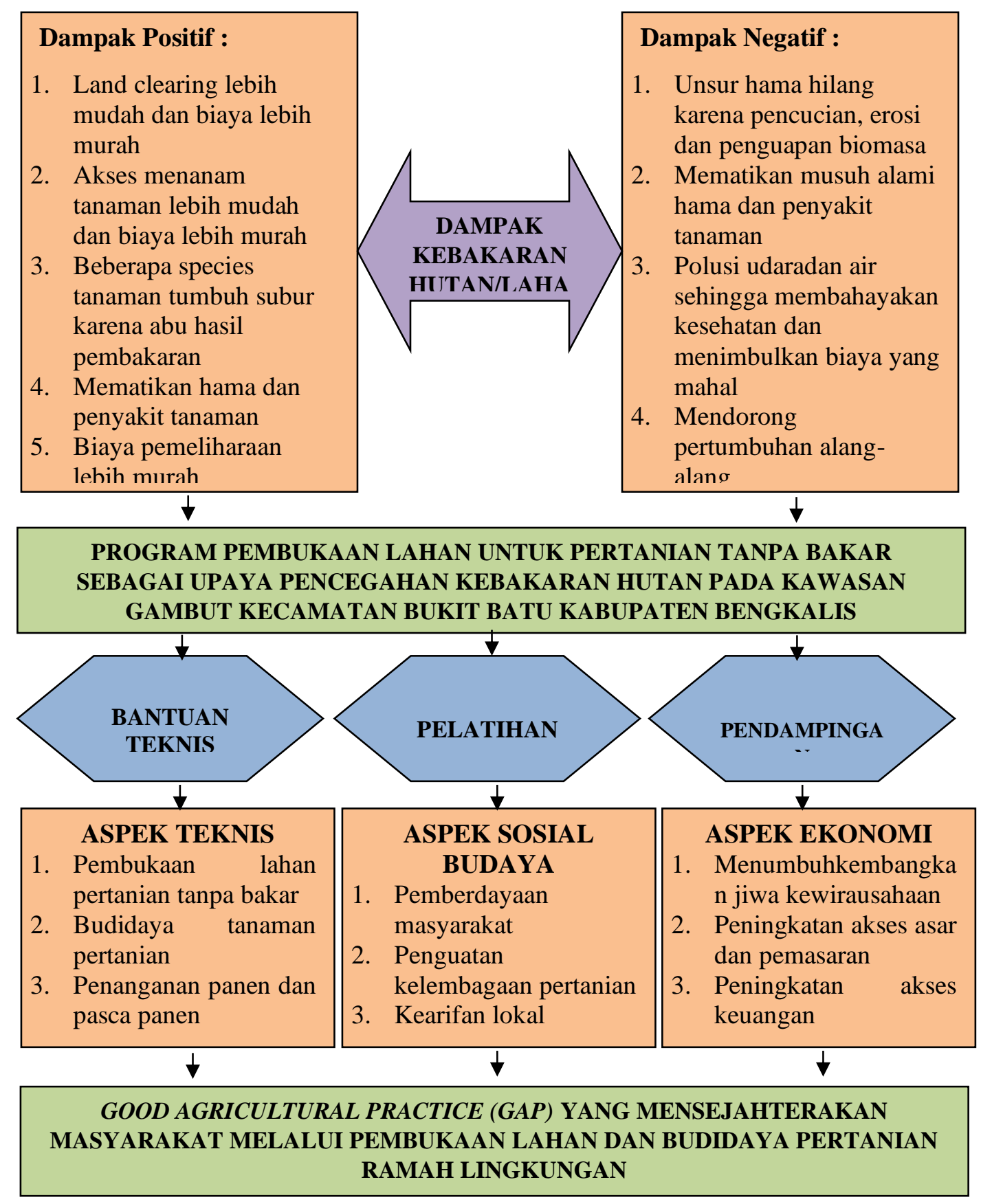

Gambar 1. Kerangka Pemikiran Pembukaan Lahan Pertanian Tanpa Bakar Lahan Sebagai Upaya Pencegahan Kebakaran Hutan serta Meningkatkan Produksi Pertanian dan Pendapatan 
Langkah - langkah Kegiatan : (1). Tahapan Kegiatan, Ada enam tahapan kegiatan yang pelu dilakukan untuk mensukseskan Program Pembukaan Lahan Pertanian Tanpa Bakar Lahan Sebagai Upaya Pencegahan Kebakaran Hutan Adapun ketujuh tahapan program tersebut meliputi: (1) Tahap Persiapan, (2) Tahap Penyusunan Program Kerja, (3) Tahap Pelaksanaan Workshop, (4) Tahap Pelaksanaan Pendampingan, (5) Tahap Monitoring dan Evaluasi Program, dan (6) Tahap Pelaporan.

Identifikasi/inventarisasi kondisi Sosial-budaya penerima manfaat (beneficeries) mencakup pengumpulan data yang menggambarkan karakteristik rumahtangga dan aktivitas sosial, atribut-atribut budaya kerja dan seni-budaya serta kearifan lokal yang ada dan dimiliki oleh masyarakat, khususnya tentang sistem atau aturanaturan yang berlaku tentang pengelolaan sumberdaya alam. Sebagai satu kesatuan, dilakukan inventarisasi kondisi ekonomi yang mencakup sumber-sumber pendapatan (jenis usaha) dan pengeluaran, dan alokasi waktu kerja baik pada usaha utama maupun usaha sampingan. Lebih jauh kondisi ekonomi mencakup perolehan gambaran tentang ketersediaan, harga dan kualitas dari prasarana/sarana produksi produksi, dan aspek pasar/pemasaran dari komoditas pertanian yang diusahakan.

\section{HASIL DAN KETERCAPAIAN SASARAN}

Api sebagai alat atau teknologi awal yang dikuasai manusia untuk mengubah lingkungan hidup dan sumberdaya alam dimulai pada pertengahan hingga akhir zaman Paleolitik, 1.400.000-700.000 tahun lalu. Sejak manusia mengenal dan menguasai teknologi api, maka api dianggap sebagai modal dasar bagi perkembangan manusia karena dapat digunakan untuk membuka hutan, meningkatkan kualitas lahan pengembalaan, memburu satwa liar, mengusir satwa liar, berkomunikasi sosial disekitar api unggun dan sebagainya (Soeriaatmadja: 1997:125).

Kebakaran hutan dan lahan bukan semata-mata karena faktor alam berupa kekeringan. Faktor alam menyediakan kondisi untuk terjadinya kebakaran, tetapi manusia juga memegang peranan penting. Kebakaran hutan yang disebabkan oleh manusia terjadi karena adanya aktivitas masyarakat di dalam dan di luar kawasan hutan. Aktifitas masyarakat di luar kawasan hutan pada saat musim kemarau adalah dengan melakukan pembakaran untuk pernbersihan lahan atau untuk membuka lahan baru bagi kegiatan pertanian dan perkebunan. Untuk memahami sumber api, perlu dibedakan jenis kebakarannya. Ada 3 (tiga) sumber api yaitu: (1). Api dari pembukaan lahan. Para pengusaha yang mengelola lahan dan petani kecil menggunakan cara pembukaan lahan yang murah dan cepat dengan membakar biomassa. Abu sisa pembakaran bisa menjadi pupuk. (2). Api dari kebakaran yang tidak disengaja. Api muncul akibat tindakan tidak hati-hati, misalnya membuang puntung rokok sembarangan, dari pembakaran sampah dan sisa-sisa perkemahan atau pembakaran untuk pembukaan lahan yang tidak terkendalisehingga kemudian menyebar. (3).Pembakaran yang disengaja, seseorang dengan sengaja membakar lahan orang lain karena dendam, marah atau agar bisa memperoleh hak atas tanah tanpa membayar ganti rugi (KMNLH dan UNDP, 1997:69).

Pembagian wilayah Desa Bukit Batu terbagi dari 3 Rukun warga (RW) dan 6 Rukun Tetangga (RT), pembagiannya berdasarkan jumlah Kartu Keluarga (KK) yang ada pada daerah tersebut. Desa Bukit Batu merupakan salah satu dari 17 Desa/Kelurahan yang ada di wilayah kecamatan Bukit Batu Kabupaten Bengkalis yang terletak + $23 \mathrm{KM}$ kearah utara dari ibu kota kecamatan dengan luas wilayah $16200 \mathrm{Km} 2$, yang memiliki batas-batas daerah sebagai berikut: (1) Sebelah timur berbatasan dengan Desa Buruk Bakul. (2). Sebelah barat berbatasan dengan Desa Sukajadi. (3). Sebelah selatan berbatasan dengan kecamatan Mandau.(4).Sebelah utara berbatasan dengan Selat Bengkalis.

Kendala yang saat ini di hadapi masyarakat petani adalah menggunakan teknologi tepat guna untuk mengembangkan potensi pengolahan tanpa bakar. Melalui kegiatan pengabdian yang telah dilakukan seperti sosialisasi, penyuluhan dan pelatihan mengenai pengelolaan hasil pertanian yang berbasis ilmu pengetahuan dan teknologi serta kearifan lokal masyarakat merasa sangat terbantu.

Berdasarkan tujuan pengabdian yang sudah ditetapkan yakni melakukan pembinaan penguatan ilmu pengetahuan dan teknologi serta kearifan lokal dalam pengelolaan perikanan, memberikan pembinaan melalui pembentukan kelompok dan kelembagaan hasil produk olahan ikan, dan memberikan pembinaan pengemasan produk dan pengurusan perizinan. Untuk tahun pertama pembinaan ilmu pengetahuan dan teknologi sudah dilakukan melalui adanya sosialisasi, penyuluhan dan pelatihan kepada masyarakat nelayan sebanyak 30 orang. Ketercapaian sasaran program dapat dijelaskan sebagai berikut: (1). Tahapan Sosialisasi: Observasi lapangan, pengumpulan data, potensi dan masalah, perkenalan dengan masyarakat sasaran, sosialisasi pada masyarakat sasaran mengenai pengenalan program pengabdian. Hasil yang didapatkan ialah diperolehnya data mengenai hasil tangkap ikan terutama ikan lomek yang setiap bulan selalu mengalami peningkatan tapi tidak 
di dukung dengan daya beli masyarakat sehingga menimbulkan masalah. Selain itu ketercapaian dari kegiatan pertama yang dilakukan adalah pemahaman yang diberikan kepada masyarakat nelayan mengenai pentingnya pengelolaan berkelanjutan dalam sector perikanan. (2). Tahapan Penyuluhan: Pengurusan perizinan kegiatan dengan perangkat desa Bukit Batu, penyampaian materi program Ketercapaian dari kegiatan yang dilakukan ialah adanya partisipasi penuh masyarakat untuk menghadiri forum diskusi untuk mendengarkan materi yang disampaikan oleh tim pengabdian. Selain itu, antusiasme masyarakat untuk mendapatkan pelatihan dan pembinaan terlihat melalui adanya diskusi dan tanya jawab. (3). Tahapan Pelatihan: Pelatihan mengenai sistem pengolahan lahan tanpa bakar yang memiliki jumlah yang cukup banyak, pengenalan teknologi yang tepat kepada masyarakat sasaran (tanggal 3-4 Agustus 2019). Hasil dari kegiatan yang dilakukan keberhasilan tim pengabdian yang dibuktikan dengan adanya pembukaan lahan tanpa bakar. (4). Tahap Evaluasi: Pengumpulan informasi dari masyarakat sasaran mengenai pelatihan yang telah dilakukan melalui adanya monitoring dan evaluasi. Menurut Peraturan Pemerintah Republik Indonesia Nomor 4 Tahun 2001 tentang Pengendalian Kerusakan dan Pencemaran Lingkungan Hidup yang Berkaitan dengan Kebakaran Hutan dan atau Lahan, yang dimaksud dengan lahan adalah "suatu hamparan ekosistem daratan yang peruntukannya untuk usaha dan atau kegiatan ladang dan atau kebun bagi masyarakat".

Penerapan teknik tanpa bakar dalam pembukaan lahan untuk berbagai tujuan mengandung dua kegiatan utama yaitu penebangan dan penumpukan. Majid (2007) mengemukakan bahwa meningkatkan efektifitas dan efisiensi pembukaan lahan, diperlukan persiapan pendahuluan untuk pelaksanaan penebangan dan penumpukan yang meliputi: (a) pengukuran luas areal, (b) pengukuran setiap blok, (c) pengukura jarak tanam, (d) pembuatan jalan masuk, (e) pembuatan konservasi air. Hal ini penting dilakukan agar penumpukan dapat dilakukan secara tepat. (a).Kelemahan Membuka Lahan Tanpa Bakar : Pembukaan lahan deng an tehnik tanpa bakar sangat tergantung pada alat berat (mekanis), sehingga hanya cocok untuk areal yang luas karena investasinya yang mahal.Selain itu, suatu jenis alat berat umumnya tidak bisa digunakan untuk semua kondisi lahan, misalnya keterbatasan lereng, lahan kering dan basah dan lain sebagainya, sehingga diperlukan pemilihan alat yang tepat. Produktivitas sangat ditentuakn oleh ketepatan alat berat yang digunakan dan keterampilan dalam mengoperasikan alat berat, sehingga diperlukan tenaga yang terampil yang adakalanya jumlahnya terbatas. Operator yang kurang terampil akan mengakibtkan erosi permukaan tanah yang semakin besar sehingga topsoil bisa terkelupas. (b). Keuntungan Membuka Lahan Tanpa Bakar, Tehnik ini dalam aplikasinya tidak terlalu tergantung pada kondisi cuaca, kecuali kondisi yang terlalu basah Karena dapat menghambat mobilitas alat berat.Selain itu, kelebihan utama tehnik ini adalah jauh lebih ramah lingkungan dibandingkan dengan tehnik tanpa bakar.Selain manfaat lingkungan dan agronomis, pembukaan lahan tanpa bakar juga memberikan nilai tambah ekonomis (Onrizal, 2008).

Hasil penelitian yang dilakukan oleh Majid (2007) menunjukan bahwa keuntungan dari pembukaan lahan tanpa bakar antara lain adalah: (a) melindungi humus dan mulsa yang telah terbentuk bertahun-tahun, (b) mempertahankan kelembaban tanah, (c) meningkatkan kandungan bahan organik tanah sehingga dapat meningkatkan kesuburan tanah, (d) mempertahankan kelestarian lingkungan, terutama tidak menyebabkan polusi udara, (e) menjaga $\mathrm{pH}$ tanah, (f) mengurangi biaya perawatan setelah penanaman, karena tanggul telah dicabut seluruhnya, dan (g) memungkinkan mekanisasi untk seluruh kegiatan pembukaan lahan, kecuali pada kondisi tertentu. Masyarakat menyatakan bahwa pengetahuan tentang pengolahan lahan dengan cara dibakar ini di dapatkan secara turun temurun dari nenek moyang. Sehingga tidak ada teknis khusus dalam pelaksananya, selain itu masyarakat juga mengatakan bahwa teknik pengolahan lahan dengan cara dibakar memberikan beberapa kelebihan diantaranya menghasilkan presentase luas areal lebih luas dan $\mathrm{pH}$ tanah meningkat yang disebabkan dari hasil pembakaran. Adapun tahap proses pengolahan lahan dengan di bakar yaitu : (1). Tebas dan Tebang, Pada tahap ini hal yang pertama dilakukan adalah menebas semak-semak atau rumput-rumput liar di sekitaran lahan menggunakan parang atau mesin pemotong rumput.Pohon-pohon yang berukuran sedang di tebang dengan menggunkan kapak sedangkan untuk pohon-pohon dengan ukuran besar di tebang menggunakan alat khusus tebang pohon atau yang biasa di sebut "Senso" oleh masyarakat. Pada proses tebas tebang ini masyarakat biasanya melakukan pada musim kemarau yang mana bertujuan untuk mempercepat proses dari pengeringan dari rumput-rumput liar dan pohon-pohon yang sudah di tebang. (2). Proses Pengeringan, Setelah proses penebasan dan penebangan selesaidilakukan maka tahap selanjutnya yang dilakukan adalah proses pengeringan, yang mana pada proses pengeringan ini dilakukan dengan cara memanfaatkan penyinaran matahari langsung jika panas matahari terik maka proses proses pengeringan akan lebih cepat. (3). Proses Pembakaran, Setelah semua vegatasi dirasa sudah cukup kering maka proses pembakaran dapat dilakukan. Alat yang dibutuhakan pada proses pembakaran ini hanya minyak tanah dan korek api atau mancis. Setelah pembakaran selesai maka lahan tersebut belum bisa ditanami secara langsung 
namun harus menunggu sekitar 1-2 minggu untuk memastikan lahan sudah tidak ada api lagi, kemudian lahan siap untuk di pancang atau ditanami tanaman secara langsung.

\section{KESIMPULAN}

\section{Kesimpulan}

Identifikasi daerah bebas asap diperlukan untuk memudahkan dalam mengevakuasi korban kebakaran. Mengingat asap yang dihasilkan dari kebakaran memberikan dampak negatif terhadap kesehatan, menyebabkan penyakit Infeksi Saluran Pernapasan Akut (ISPA), alergi kulit, asma dan lain-lain. Desa binaan dengan focus pada System pengolahaan lahan tanpa bakar melibatkan masayarakat, pemadaman api atau pencegahan penjalaran api lebih besar dilakukan dengan cara: (1). Pembuatan aliran api atau jalur pemadaman kebakaran hutan dan lahan. Lebar dan jarak aliran api dari areal yang terbakar tergantung pada tipe kebakaran, arah, dan kecepatan angin, keadaan topografi dan keadaan kekeringan biomasa, kesediaan personalia, alat dan bahan pemadaman api. (2). Pembuatan jalur pemadaman kebakaran terbalik (back firing). Metode ini dapat digunakan bila kecepatan angin kecil dan tipe kebakaran bawah atau permukaan. (3). Pemadaman api secara langsung. Metode ini dapat digunakan bila personalia siap serta api kecil dan kebakaran belum meluas.

\section{Saran}

(a) Tindakan Pasca Kebakaran Lahan, Kebakaran berdampak buruk tidak hanya bagi lingkungan dan aspek kesehatan, beberapa upaya juga perlu dilakukan guna memperbaiki keadaan lahan yang telah terbakar, Beberapa tindakan sebagai upaya tindakan pasca kebakaran. (b). Penilaian Dampak Kebakaran, Penilaian dampak kebakaran dilakukan setelah terjadinya kebakaran, dengan tujuan untuk mengetahui dampak yang merugikan bagi manusia dan lingkungan dari berbagai sudut pandang, baik dari segi ekonomi, ekologi, sosial maupun kesehatan. Banyak penelitian telah dilakukan untuk mengetahui dampak kebakaran, diantaranya dampak akibat kebakaran besar tahun 1997/1998 yang melanda Indonesia dan negara-negara tetangga baik mengenai luasan yang terbakar maupun kerugian-kerugiannya.

\section{DAFTAR PUSTAKA}

Agus, F., \& I. G. Subiksa. 2008. Lahan gambut: potensi untuk pertanian dan aspek lingkungan. Balai Penelitian Tanah. Badan Litbang Pertanian. World Agroforestry Centre. Bogor.

BALIBANG PEMPROV RIAU. 2010. Seminar dan Lokakarya: Pengelolaan Terpadu Lingkungan Perkebunan Kelapa Sawit Berkelanjutan di Provinsi Riau

BBSDLP Balai Besar Litbang Sumberdaya Lahan Pertanian. 2009. Identifikasi dan Karakterisasi Lahan Rawan longsor dan Rawan Erosi di Dataran Tinggi untuk Mendukung Keberlanjutan Pengelolaan Sumberdaya Lahan Pertanian. Laporan Tengah Tahun, DIPA 2009. Bogor: Balai Besar Litbang Sumberdaya Lahan Pertanian.

Darmawan, T., \& Masroh, A. H. 2004. Pentingnya Nilai Tambah Produk Pangan Dalam Buku Pertanian Mandiri. Penebar Swadaya. Jakarta.

Dinas Perkebunan Provinsi Riau. 2009. Laporan Tahun. Dinas Perkebunan Provinsi Riau. Pekanbaru

Fadila, Ila. 2011. Potensi Sagu dalam Upaya Diversifikasi Pangan. Universitas Terbuka. Tangerang Selatan.

Fahroji. 2011. Pengolahan Sagu. Balai Pengkajian Teknologi Pertanian (BPTP) Riau. Pekanbaru.

Hariandja, M. T. E. 2002. Manajemen Sumber Daya Manusia. Grasindo. Jakarta

Hariyanto, B. 2011. Manfaat Tanaman Sagu (Metroxylon sp) dalam Penyediaan Pangan dan dalam Pengendalian Kualitas Lingkungan. Jurnal Teknik Lingkungan, 12(2), 143 - 152.

Huneryager \& Heckman. 1992. Partisipasi dan Dinamika Kelompok. Semarang: Dahara Priza

Sardjono, A., \& Mustofa. 2004. Mosaik Sosiologis Kehutanan: Masyarakat Lokal, Politik dan Kelestarian Sumber Daya. Yogyakarta. Debut Press.

Soeriaatmadja. 1997. Ilmu Lingkungan. ITB Press. Bandung

Suharto., \& T. Iryanto. 1989. Kamus Bahasa Indonesia Terbaru, Surabaya. Penerbit INDAH. 